DOI 10.5862/JEST.249.11

УДК 539.232

E.A. Bogdanov, E.G. Chupakhin, E.B. Sotnikov, E.S. Vasilyeva, S.S. Bulanov, M.V. Patrushev, N.N. Shusharina, A.Y. Goikhman

\title{
NEW MATERIALS FOR DNA ISOLATION
}

\author{
Е.А. Богданов, Е.Г. Чупахин, Е.Б. Сотников, Е.С. Васильева, \\ С.С. Буланов, М.В. Патрушев, Н.Н. Шушарина, А.Ю. Гойхман
}

НОВЫЕ МАТЕРИАЛЫ ДЛЯ ВЫДЕЛЕНИЯ ДНК

\begin{abstract}
Except silicon dioxide, commonly used for DNA isolation, such metal oxides $(\mathrm{V}) \mathrm{as}_{2} \mathrm{Ta}_{2} \mathrm{O}_{5}, \mathrm{Nb}_{2} \mathrm{O}_{5}$ and $\mathrm{V}_{2} \mathrm{O}_{5}$ were proposed for this purpose. A method for covering magnetic iron-based nanoparticles with metal oxides (V) was suggested. The synthesized nanoparticles were used for DNA extraction and the amount of isolated DNA was compared with the commercially available magnetic particles coated with silicon dioxide. Magnetic nanoparticles covered with $\mathrm{Ta}_{2} \mathrm{O}_{5}$ and $\mathrm{Nb}_{2} \mathrm{O}_{5}$ showed- a greater adsorption capacity as compared with the same nanoparticles covered with silica and commercial samples. The synthesized nanoparticles can be suitable for DNA extraction in clinical or research laboratories. The functional thin films for fast and effective DNA extraction are of great interest for neurobiology investigations.
\end{abstract}

SOLGEL; THIN FILMS; DNA, MAGNETICAL NANOPARTICLES; XPS.

За исключением диоксида кремния, обычно используемого для выделения ДНК, для этой цели были предложены такие оксиды металлов $(\mathrm{V})$, как $\mathrm{Ta}_{2} \mathrm{O}_{5}, \mathrm{Nb}_{2} \mathrm{O}_{5}$ и $\mathrm{V}_{2} \mathrm{O}_{5}$. В данной статье рассмотрен метод покрытия этими оксидами магнитных наночастиц на основе железа, исследованы химические и структурные свойства. Синтезированные наночастицы были использованы для выделения ДНК, проведено сравнение с имеющимися в продаже магнитными частицами, покрытыми диоксидом кремния. Магнитные наночастицы, покрытые $\mathrm{Ta}_{2} \mathrm{O}_{5}$ и $\mathrm{Nb}_{2} \mathrm{O}_{5}$ показывают наибольшую адсорбционную способность по сравнению с наночастицыми, покрытыми диоксидом кремния и с коммерчески доступными. Синтезированные наночастицы могут быть использованы для экстракции ДНК в клинических или научно-исследовательских лабораториях. Функциональные тонкие пленки для быстрой и эффективной экстракции ДНК представляют большой интерес для исследований в нейробиологии.

ТОНКИЕ ПЛЕНКИ; ЗОЛЬ-ГЕЛЬ; ДНК; МАГНИТНЫЕ НАНОЧАСТИЦЫ; РФЭС.

\section{Introduction}

Over the last decade the studies on the magnetic nanoparticles (MNP) have become popular in wide range of biomedical applications, such as biosensors, contract agents for magnetic resonance imaging, drug delivery, etc [1-5]. One of the most common applications of magnetic nanoparticles is DNA isolation. In that application the surface of magnetic nanoparticles is covered with materials which are active for DNA isolation. So, at the first step MNP surface actively absorbes DNA molecules and at the next step MNP are efficiently separated from chemical or biological suspensions with the magnetic field [6]. Magnetic separation is recognized as simple and effective method for nucleic acids purification.

On the other hand materials with high surface area, such as nanoparticles, are preferred for the nucleic acids binding. Magnetic particles with shape of nanospheres, are more preferred in the process of selection, as they have a greater ability to bind-conductive [7]. Many different DNA isolation kits with magnetic particles are presents in the market, such as: AGOWA ${ }^{\circledR}$ mag, Dynabeads ${ }^{\circledR}$ DNA and other [8]. In general, surface cover materials of these magnetic nanoparticles is silicon dioxide $\mathrm{SiO}_{2}$ or a compound based on it [9-13]. 
The principle of DNA isolation on silicon dioxide matrix is based on the high-affinity of negatively charged DNA strands to the positively charged sodium ions, which are in turn bound to negatively charged particles of silicon dioxide. Sodium ions act as a cation bridges, which attract negatively charged oxygen of the phosphates in the nucleic acid chain. Sodium ions treat the bonds between hydrogen in water and negatively charged oxygen ions on silica surface under high salt $(p H \leqslant 7)$. Thus, DNA is firmly connected to the matrix. Purified DNA molecules can be eluted by low salt solution using Elution buffer or distilled water [14-16](fig. 1).

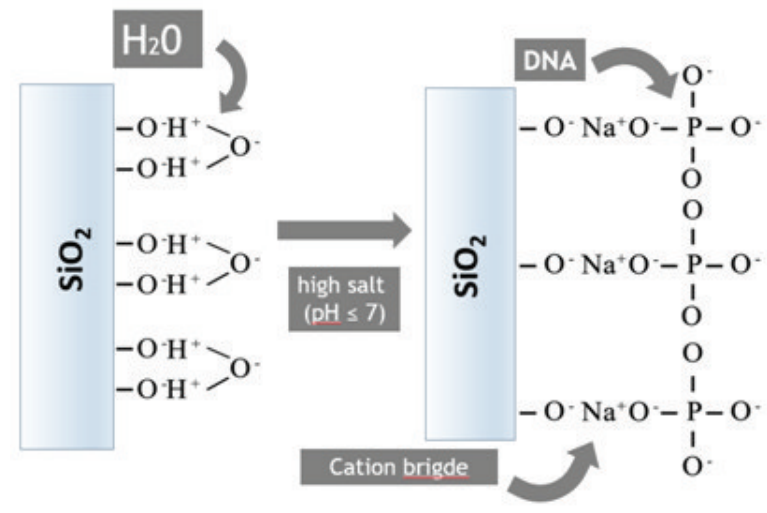

Fig. 1. $\mathrm{SiO}_{2}-\mathrm{DNA}$ interaction under high salt $(p H \leqslant 7)$

In the previous work [17] it was assumed that using of metal oxides $(\mathrm{V})$ (tantalum, niobium and vanadium) would provide more effective DNA extraction than silicon dioxide. Since their crystal lattices close to stoichiometric ratio 2:5, while the silicon dioxide stoichiometric composition is close to $1: 2$. More effective DNA extraction can be explained by the ability of metal oxide (V) surface to form $25 \%$ more chemical bonds than $\mathrm{SiO}_{2}$ according to oxides stoichiometry. In recent study we proposed a technological framework for fabrication of the magnetic iron-based nanoparticles covered by $\mathrm{SiO}_{2}$ and $\mathrm{Ta}$, $\mathrm{Nb}, \mathrm{V}$ oxides in order to verify this assumption. Synthesised magnetic nanoparticles with bioactive surface were used for DNA extraction and quantitative characteristics of isolated DNA [18] were compared with commercial Syntol ${ }^{\circledR}$ magnetic particles.

\section{Materials and Methods}

The non-agglomerative spherical magnetic nanoparticles of $\mathrm{Fe}_{3} \mathrm{O}_{4}$ were produced by aerosol CVD synthesis method. The experimental setup for the
CVC synthesis of nanoparticles has been described elsewhere $[19,20]$. Briefly, the liquid precursor, $\mathrm{Fe}(\mathrm{CO})_{5}$, was heated in a bubbler, evaporate and transported by inert gas (argon or helium) flow into a heated tubular furnace. The tubular furnace provides a heat source for the controlled decomposition of the precursor. The product of the precursor decomposition was collected in a vacuum chamber on the surface of a rotating chiller cooled by liquid nitrogen. An iron particle passivation process was achieved by dosing oxygen before opening the chamber to air. The precursor decomposition temperature was set at $400^{\circ} \mathrm{C}$. After the synthesis initial Fe-based nanoparticles have core-shell structure: core is pure iron and shell is 1-2 $\mathrm{nm}$ thick magnetite. SEM micrograph of as-produced nanoparticles are shown in the fig. 2 .

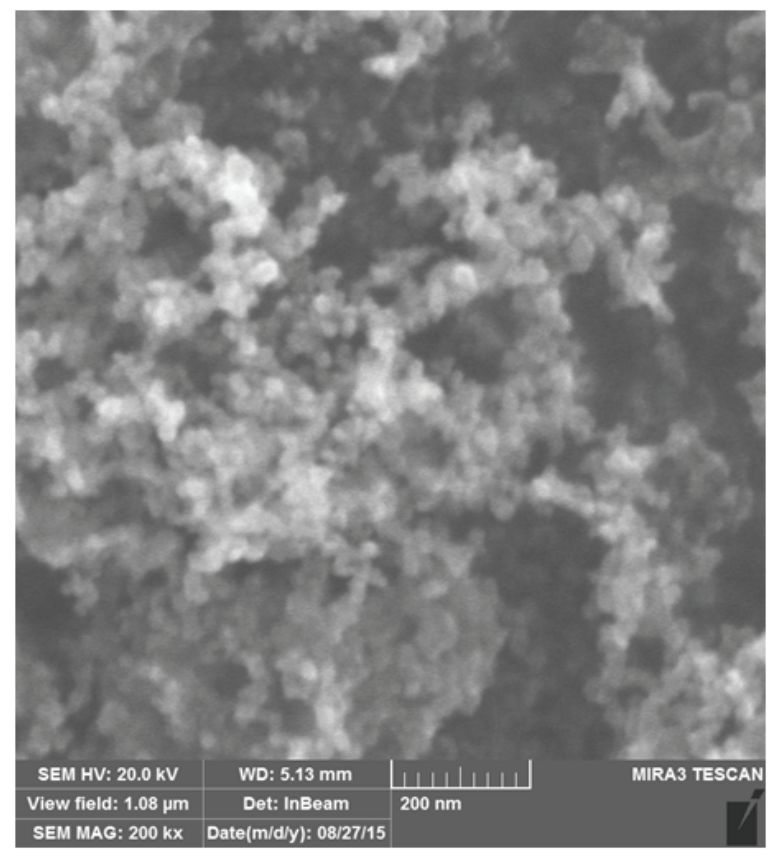

Fig. 2. SEM electron micrograph of $\mathrm{Fe}_{3} \mathrm{O}_{4} \mathrm{MNPs}$

Magnetic nanoparticles we covered with oxides using sol-gel synthesis method. MNPs were covered with metal oxides in the following compositions: $\mathrm{Fe}_{3} \mathrm{O}_{4} / \mathrm{SiO}_{2} ; \mathrm{Fe}_{3} \mathrm{O}_{4} / \mathrm{SiO}_{2} / \mathrm{Nb}_{2} \mathrm{O}_{5} ; \mathrm{Fe}_{3} \mathrm{O}_{4} / \mathrm{SiO}_{2} / \mathrm{Ta}_{2} \mathrm{O}_{5}$; $\mathrm{Fe}_{3} \mathrm{O}_{4} / \mathrm{SiO}_{2} / \mathrm{V}_{2} \mathrm{O}_{5}$. All reagents and materials are commercially available in Sigma Aldrich: tantalum (V) chloride, niobium (V) chloride, vanadium (V) oxide, isoamyl alcohol, thionyl chloride and ethanol.

The structure of the materials was analyzed by scanning electron microscopy (SEM, Leo DSM 982 Gemini and JEOL JSM_7500F microscopes). The 
phase composition of the materials was studied by X-ray photoelectron spectroscopy (XPS) on a Thermo Scientific K-alpha spectrometer (USA) with monochrome radiation source $(\mathrm{Al} \mathrm{K} \alpha)$. Ion etching of samples was carried out until the element content became constant as a function of the etching depth.

The biological material obtaining and DNA isolation process was carried out in the Immanuel Kant Baltic Federal University.

Real-time polymerase chain reaction (RT-PCR) was carried out using PCR CFX96 Real-Time PCR Detection System («Bio-Rad», USA). PCR tube contained $20 \mu \mathrm{l}$ reaction mixture: DNA-polymerase buffer Taq ("Evrogen", Russia) - 1x, 2,5 $\mathrm{mM} \mathrm{MgCl}_{2}$ («Syntol», Russia, , $25 \mathrm{mM}$ of each dNTPs («Syntol», Russia, Taq-polymerase («Syntol», Russia) - 1x, the neurotrophin receptor gene primer - TrkB - 0,5 $\mu \mathrm{M}$. The amplification reaction was started with the following conditions: $95{ }^{\circ} \mathrm{C}$ for $3 \mathrm{~min}$ (once), $95{ }^{\circ} \mathrm{C}$ for $10 \mathrm{~s}, 63{ }^{\circ} \mathrm{C}$ for $40 \mathrm{~s}$, (50 cycles).

\section{Results and discussion}

\section{Preparation of metal oxides (V) thin film on the surface of MNPs precursors}

At the first step the nanoparticles were covered by silicon dioxide thin films by sol-gel synthesis method by using the well-known process described in [21]. We mixed $15 \mathrm{mg}$ of MNPs, $500 \mu \mathrm{l}$ ethanol, $500 \mu \mathrm{l}$ deionized and deoxygenated water, $50 \mu \mathrm{l}$ ammonium solution ( $25 \% \mathrm{wt}$ ) and $3 \mu \mathrm{l}$ tetraethoxysilane. Mixture was shaken on vortex and sonicated for $0,5 \mathrm{~h}$. The tube with MNPs was placed in the magnetic rack/ After the separation particles, liquid was removed by pipetting.

Silicon dioxide thin film on the surface of MNPs was used as a substrate for formation of metal oxide (V) thin-films. For the synthesis of thin layers of metal oxides on the silica surface of MNPs corresponding etoxides $\left(\mathrm{Nb}\left(\mathrm{C}_{2} \mathrm{H}_{5} \mathrm{O}\right)_{5} ; \mathrm{Ta}\left(\mathrm{C}_{2} \mathrm{H}_{5} \mathrm{O}\right)_{5}\right)$ were used as precursors for $\mathrm{Ta}$ and $\mathrm{Nb}$ oxides coating and vanadium oxychloride $\left(\mathrm{VOCl}_{3}\right)$ was used for vanadium ones. Precursors were synthesized in laboratory using reaction between metal chlorides and absoluted ethanol [22-24], excess of $\mathrm{HCl}$ was removed by reaction with gaseous ammonium.

For the synthesis $15 \mathrm{mg} \mathrm{MNPs}\left(\mathrm{Fe} / \mathrm{SiO}_{2}\right)$ - coated by $\mathrm{SiO}_{2}$ (described above), was added $0.7 \mathrm{ml}$ deionized water, $0,05 \mathrm{ml} 25 \%$ ammonia solution for $\mathrm{HCl}$ neutralizing (which released during $\mathrm{VOCl}_{3}$ hydrolysis process) and $0.01 \mathrm{ml}$ ethylenglycol (is a complexing agent). In the resulting solution dropwise $0.03 \mathrm{ml} 10 \%$ solution corresponding precursor $-\left(\mathrm{Nb}\left(\mathrm{C}_{2} \mathrm{H}_{5} \mathrm{O}\right)_{5}\right.$; $\mathrm{Ta}\left(\mathrm{C}_{2} \mathrm{H}_{5} \mathrm{O}\right)_{5}-$ wherein the metal oxides are sol. The mixture was stirred for 10 min and placed on an ultrasonic bath under room temperature for $10 \mathrm{~min}-3$ times. The tube with MNPs was placed in the magnetic rack, after the separation particles, liquid was removed by pipetting. Then MNPs were washed three times with $1 \mathrm{ml}$ deionized water under magnetic separation process.

As the results four type of coating had been synthesized on the surface of MNPs: 1) $\mathrm{Fe} / \mathrm{SiO}_{2}$; 2) $\mathrm{Fe} /$ $\mathrm{SiO}_{2} / \mathrm{Ta}_{2} \mathrm{O}_{5}$; 3$\left.) \mathrm{Fe} / \mathrm{SiO}_{2} / \mathrm{Nb}_{2} \mathrm{O}_{5} ; 4\right) \mathrm{Fe} / \mathrm{SiO}_{2} / \mathrm{V}_{2} \mathrm{O}_{5}$. These particles were used in further experiments.

\section{Particles characterization}

Chemical composition of MNP's surface with different coatings was studied by X-ray photoelectron spectroscopy (XPS) The X-ray beam size was 400 microns. Overview spectra were obtained with electron transmission energy $200 \mathrm{eV}$ with step $1,0 \mathrm{eV}$, the number of scans was 15 . High-resolution spectra $(\mathrm{Si}$, $\mathrm{Nb}, \mathrm{Ta}, \mathrm{V}, \mathrm{O}$ ) were obtained with electron transmission energy $50 \mathrm{eV}$ with step $1,0 \mathrm{eV}$, the number of scans 7. Cleaning of the samples after air contamination was carried out by $\mathrm{Ar}^{+}$ion etching under at 200 $\mathrm{eV}$ for $30 \mathrm{sec}$. XPS spectra before and after ion etching are shown in fig. 3 . The ion beam with $20 \mathrm{~mm}$ diameter had a uniform radial distribution of ion current.

SEM electron micrographs of MNPs coated by silica and niobium oxide are shown in fig. 4 .

SEM electron micrographs confirmed the fact that coated MNPs do not form agglomerates in fluids. The average MNP size is $25 \mathrm{~nm}$, MNPs shape is close to spherical.

\section{Testing MNP's for DNA isolation}

The sorption efficiency of metal oxides (V) was analysed by conducting real-time polymerase chain reaction. For this purpose we isolated DNA using standard protocol based on magnetic particles DNA isolation method, described in [10]. In order to determine the optimal conditions for DNA binding by metal oxides $(\mathrm{V})$ we have changed some parameters of standard protocol. 
a)

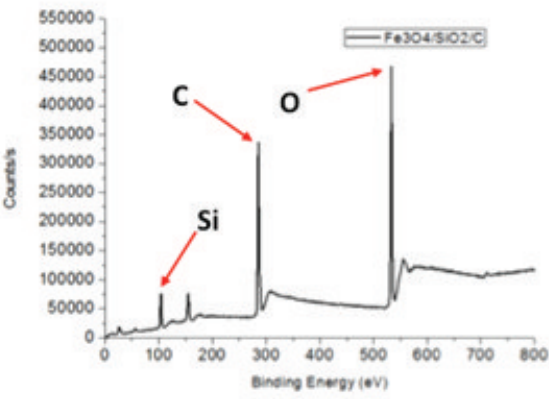

c)

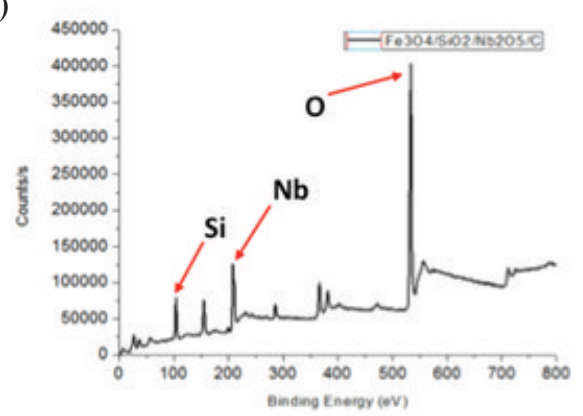

b)

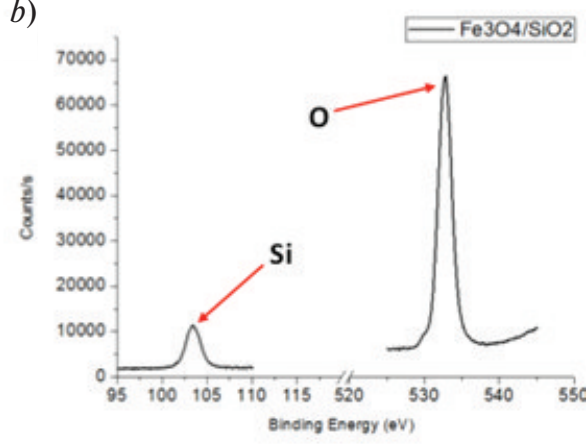

d)

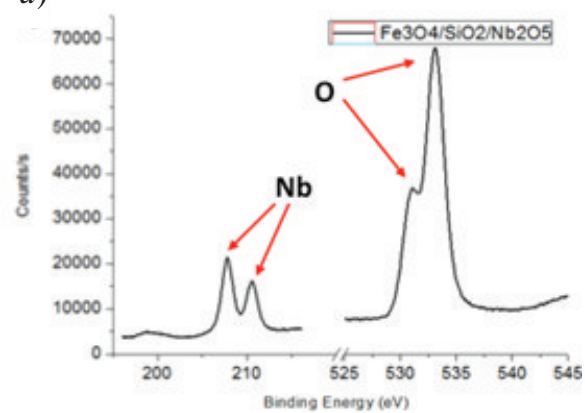

Fig. 3. XPS spectra of $\mathrm{Fe}_{3} \mathrm{O}_{4} / \mathrm{SiO}_{2}$ and $\mathrm{Fe}_{3} \mathrm{O}_{4} / \mathrm{SiO}_{2} / \mathrm{Nb}_{2} \mathrm{O}_{5}$ before $(a, c)$ and after $(b, d)$ etching
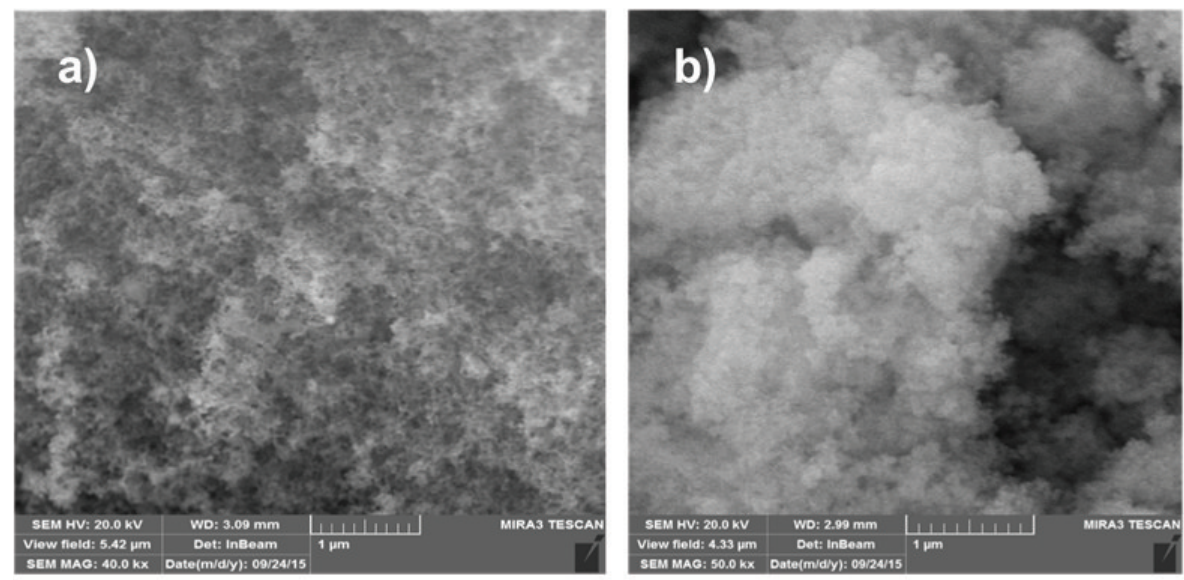

Fig. 4. SEM electron micrographs of: $a$ ) MNPs coated $\mathrm{SiO}_{2}$,

b) MNPs coated $\mathrm{SiO}_{2} / \mathrm{Nb}_{2} \mathrm{O}_{5}$.

DNA isolation was carried out with standard protocol, described previously, with metal oxides (V) and commercially available sorbents ("Syntol", Russia). The resulting amplification curves are shown in fig. 5.

Basing on the values of average DNA threshold cycles (fig. 5) we can conclude that MNPs covered by niobium oxide (V) thin films have the highest sorption properties.
The worst result was shown by commercial MNPs produced by «Syntol» (Russia). The average difference in threshold cycles between the MNPs covered by metal oxides (V) and MNPs covered by silicon dioxide («Syntol») was about 3 cycles.

This phenomenon can be explained by the difference in amount of formed chemical bonds available for DNA binding and it turn to decreased the quantity of extracted DNA. 


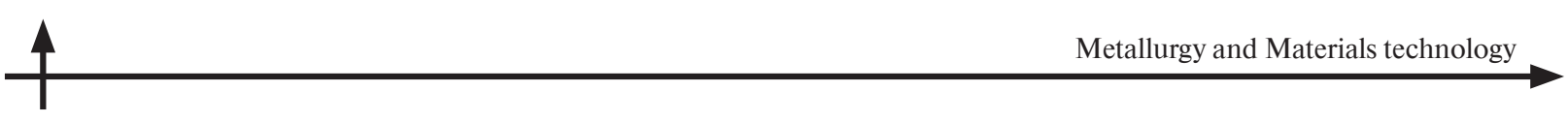

a)

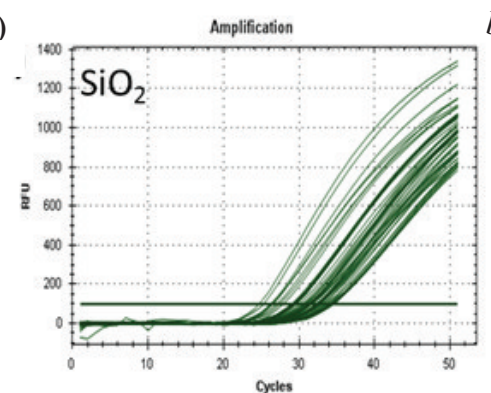

c)

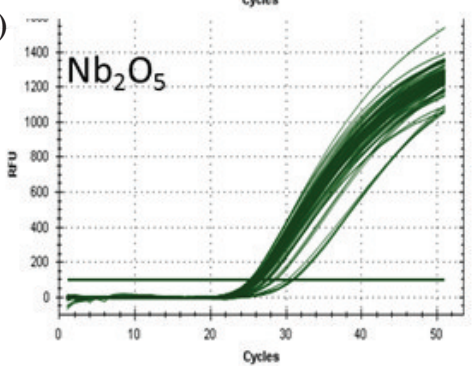

b)

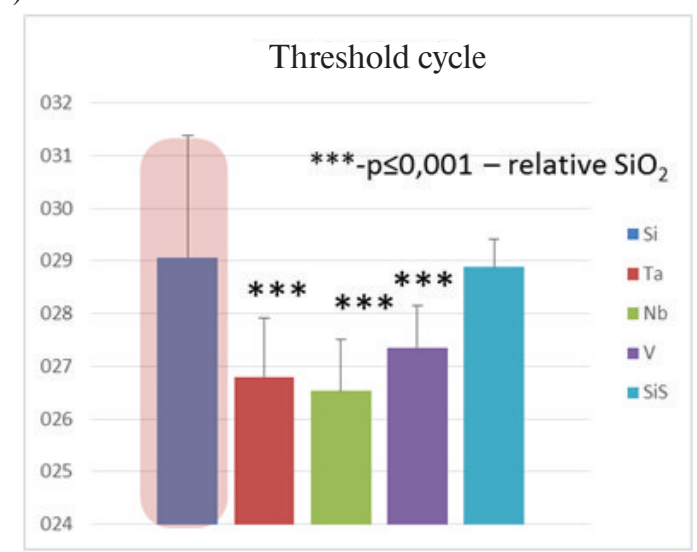

Fig. 5. The amplification curves obtained during the real-time PCR for isolated DNA using the standard protocol with $\mathrm{SiO} 2$ and $\mathrm{Nb} 2 \mathrm{O} 5$ as sorption materials $(a)$ and $(c)$ respectively and average DNA threshold cycles with silicon dioxide; tantalum oxide (V); niobium oxide $(\mathrm{V})$; vanadium oxide $(\mathrm{V})$; silicon dioxide («Syntol») as sorption materials

\section{Conclusions}

The metal oxides (V) have ability to form additional chemical bonds, which increase sorption capacity of MNPs covered by the metal oxides (V) thin film for DNA biding. However, the total usable area of surface is a dominant factor for achieving high sensitivity and efficiency of DNA extraction using MNPs. This fact was confirmed by the example of MNPs obtained by aerosol synthesis with silica compound as a sorbent, obtained by sol-gel method and commercial magnetic particles "Syntol". Furthermore, obtained results suggest that the developed thins film materials based on metal oxides $(\mathrm{V})$ are suitable for the DNA extraction in clinical or research laboratories. Described above investigation results are relevant for future developments of micro- and nanodiagnostic systems, which might be realized "on-chip", since the thin film materials are shown prospective for DNA isolation.

\section{Acknowledgments}

The authors are grateful for financial support from Russian Science Foundation: Grant № 15-1210038 .

\section{REFERENCES}

1. Takenaka S. [et al.] DNA sensing on a DNA probemodified electrode using ferrocenylnaphthalene diimide as the electrochemically active ligand. Analytical chemistry. 2000. Vol. 72. № 6. P. 1334-1341.

2. Azek F., Grossiord C., Joannes M. [et al.] Hybridization assay at a disposable electrochemical biosensor for the attomole detection of amplified human cytomegalovirus DNA. Analytical biochemistry. 2000. Vol. 284. P. $107-113$.

3. Drummond T.G., Hill M.G., and Barton J.K. Electrochemical DNA Sensors. Nature Biotechnology. 2003. Vol. 21. P. 1192-1199.

4. Willard M.A., Kurihara L.K., Carpenter E.E., Calvin S., Harris V. G. In Encyclopedia of Nanoscience and Nanotechnology. Vol. 1 / Ed. H.S. Nalwa. American Scientific Publishers, Stevenson Rauch, CA. 2004. 815 p.
5. Nanoscience and Nanotechnology, Stevenson Ranch, CA . American Scientific Publishers, 2004. 815 p.

6. McBain S.C., Yiu H.P., Dobson J. Magnetic nanoparticles for gene and drug delivery. International journal of nanomedicine. 2008. Vol. 3. № 2. P. 169-180.

7. Davies M.J., Taylor J.I., Sachsinger N., Bruce I.J. Isolation of plasmid DNA using magnetite as a solidphase adsorbent. Analytical biochemistry. 1998. Vol. 262. P. 92-94.

8. United States patent US №6855499 B1. Magnetic isolation and purification of nucleic acids / R.D. Nargessi. Priority 16 February 2001.

9. Berensmeier S. Magnetic particles for the separation and purification of nucleic acids. Applied Microbiology and Biotechnology. 2006. Vol. 73. №. 3. P. 495-504. 
10. Vogelstein B., Gillespie D. Preparative and analytical purification of DNA from agarose. Proceedings of the National Academy of Sciences. 1979. Vol. 76. № 2. P. 615-619.

11. Boom R., Sol C.J., Salimans M.M., Jansen C.L., Wertheim-van Dillen P.M., van der Noordaa J. Rapid and simple method for purification of nucleic acids. Journal of clinical microbiology. 1990. Vol. 28. № 3. P. 495-503.

12. Boom R., Sol C., Beld M., Weel J., Goudsmit J., Wertheim-van Dillen P. Improved silica-guanidinium thiocyanate DNA isolation procedure based on selective binding of bovine alpha-casein to silica particles. Journal of clinical microbiology. 1999. Vol. 37. № 3. P. 615-619.

13. Tian H., Hühmer A. F. R., Landers J. P. Evaluation of silica resins for direct and efficient extraction of DNA from complex biological matrices in a miniaturized format. Analytical biochemistry. 2000. Vol. 283. № 2. P. 175-191.

14. Breadmore M. C. et al. Microchip-based purification of DNA from biological samples. Analytical chemistry. 2003. Vol. 75. № 8. P. 1880-1886.

15. Esser K. H., Marx W. H., Lisowsky T. MaxXbond: first regeneration system for DNA binding silica matrices.

16. Gribanov O. G. [et al.] A simple method for RNA isolation and purification. Bioorganicheskaia khimiia. 1997. Vol. 23. № 9. S. 763-765.

17. Parida S. K. [et al.] Adsorption of organic molecules on silica surface. Advances in colloid and interface science. 2006. Vol. 121. № 1. P. 77-110.

18. Bogdanov E., Dominova I., Shusharina N., Botman S., Kasymov V. [et al.] Silicon Dioxide Thin Film Nature Methods. 2006. № 3. P. 1-2.

Mediated Single Cell. Nucleic Acid Isolation. PLoS ONE. 2013. Vol. 8. № 7. P. e68280.

19. Schefe J. H., Lehmann K. E., Buschmann I. R., Unger T., Funke-Kaiser H. Quantitative real-time RTPCR data analysis: current concepts and the novel "gene expression's CT difference" formula. Journal of Molecular Medicine. 2006. Vol. 84. № 11. P. 901-910.

20. Choi C.J., Kim B.K., Tolochko O. [et al.] Preparation and characterization of magnetic $\mathrm{Fe}, \mathrm{Fe} / \mathrm{C}$ and $\mathrm{Fe} / \mathrm{N}$ nanoparticles synthesized by chemical vapor condensation process. Reviews on Advanced Materials Science. 2003. Vol. 5. № 5. P. 487-492.

21. Tolochko O.V., Arif M., Lee D.W., Choi C.J., Kim D. Structure and magnetic properties of iron based nanoparticles with oxide shells. Technical Physics Letters. 2005. Vol. 31. № 9. P. 779-781.

22. Wang J. [et al.] Synthesis of Fe3O4, SiO2, $\mathrm{ZnO}-\mathrm{Ag}$ core-shell microspheres for the repeated photocatalytic degradation of rhodamine $\mathrm{B}$ under UV irradiation. Journal of Molecular Catalysis A: Chemical. 2015. Vol. 406. P. 97-105.

23. Epifani M. [et al.] Soft chemistry routes to transparent metal oxide thin films. The case of sol-gel synthesis and structural characterization of Ta2O5 thin films from tantalum chloromethoxide. Thin Solid Films. 2014. Vol. 555. P. 39-41.

24. Wolf M. J. [et al.] Fabrication of ultrathin films of Ta2O5 by a sol-gel method. Thin solid films. 2013. Vol. 527. P. 354-357.

25. Tyree S. Inorganic Syntheses. Volume IX. McGraw-Hill, New-York, 1967. 80 p.

\section{СПИСОК ЛИТЕРАТУРЫ}

1. Takenaka S. [et al.] DNA sensing on a DNA probemodified electrode using ferrocenylnaphthalene diimide as the electrochemically active ligand // Analytical chemistry. 2000. Vol. 72. № 6. P. 1334-1341.

2. Azek F., Grossiord C., Joannes M. [et al.] Hybridization assay at a disposable electrochemical biosensor for the attomole detection of amplified human cytomegalovirus DNA // Analytical biochemistry. 2000. Vol. 284. P. 107-113.

3. Drummond T.G., Hill M.G., Barton J.K. Electrochemical DNA Sensors // Nature Biotechnology. 2003. Vol. 21. P. 1192-1199.

4. Willard M. A., Kurihara L. K., Carpenter E. E., Calvin S., Harris V. G. In Encyclopedia of Nanoscience and Nanotechnology. Vol. 1 / Ed. H.S. Nalwa. American Scientific Publishers, Stevenson Rauch, CA. 2004. 815 p.

5. Nanoscience and Nanotechnology, Stevenson Ranch. CA: American Scientific Publishers, 2004. 815 p.

6. McBain S.C., Yiu H.P., Dobson J. Magnetic nanoparticles for gene and drug delivery // International journal of nanomedicine. 2008. Vol. 3. № 2. P. 169-180.
7. Davies M.J., Taylor J.I., Sachsinger N., Bruce I.J. Isolation of plasmid DNA using magnetite as a solidphase adsorbent // Analytical biochemistry. 1998. Vol. 262. P. 92-94.

8. United States patent US №6855499 B1. Magnetic isolation and purification of nucleic acids // R.D. Nargessi. Priority 16 February 2001.

9. Berensmeier S. Magnetic particles for the separation and purification of nucleic acids // Applied Microbiology and Biotechnology. 2006. Vol. 73. 2001.

10. Vogelstein B., Gillespie D. Preparative and analytical purification of DNA from agarose // Proceedings of the National Academy of Sciences. 1979. Vol. 76. № 2. P. 615-619.

11. Boom R., Sol C.J., Salimans M.M., Jansen C.L., Wertheim-van Dillen P.M., van der Noordaa J. Rapid and simple method for purification of nucleic acids // Journal of clinical microbiology. 1990. Vol. 28. № 3. P. 495-503.

12. Boom R., Sol C., Beld M., Weel J., Goudsmit J., Wertheim-van Dillen P. Improved silica-guanidinium thiocyanate DNA isolation procedure based on selective binding of bovine alpha-casein to silica particles // 
Journal of clinical microbiology. 1999. Vol. 37. № 3. P. 615-619.

13. Tian H., Hühmer A. F. R., Landers J. P. Evaluation of silica resins for direct and efficient extraction of DNA from complex biological matrices in a miniaturized format // Analytical biochemistry. 2000. Vol. 283. № 2. P. 175-191.

14. Breadmore M.C. [et al.] Microchip-based purification of DNA from biological samples // Analytical chemistry. 2003. Vol. 75. № 8. P. 1880-1886.

15. Esser K. H., Marx W. H., Lisowsky T. MaxXbond: first regeneration system for DNA binding silica matrices // Nature Methods. 2006. № 3. P. 1-2.

16. Gribanov O.G. [et al.] A simple method for RNA isolation and purification // Bioorganicheskaia khimiia. 1997. Vol. 23. № 9. P. 763-765.

17. Parida S. K. [et al.] Adsorption of organic molecules on silica surface // Advances in colloid and interface science. 2006. Vol. 121. № 1. P. 77-110.

18. Bogdanov E., Dominova I., Shusharina N., Botman S., Kasymov V. [et al.] Silicon Dioxide Thin Film Mediated Single Cell. Nucleic Acid Isolation // PLoS ONE. 2013. Vol. 8. № 7. P. e68280.

19. Schefe J.H., Lehmann K.E., Buschmann I.R., Unger T., Funke-Kaiser H. Quantitative real-time RTPCR data analysis: current concepts and the novel "gene expression's CT difference" formula // Journal of Molecular Medicine. 2006. Vol. 84. № 11. P. 901-910.

20. Choi C.J., Kim B.K., Tolochko O. et al. Preparation and characterization of magnetic $\mathrm{Fe}, \mathrm{Fe} / \mathrm{C}$ and $\mathrm{Fe} / \mathrm{N}$ nanoparticles synthesized by chemical vapor condensation process // Reviews on Advanced Materials Science. 2003. Vol. 5. № 5. P. 487-492.

21. Tolochko O.V., Arif M., Lee D.W., Choi C.J., Kim D. Structure and magnetic properties of iron based nanoparticles with oxide shells // Technical Physics Letters. 2005. Vol. 31. № 9. P. 779-781.

22. Wang J. [et al.] Synthesis of Fe3O4, SiO2, $\mathrm{ZnO}-\mathrm{Ag}$ core-shell microspheres for the repeated photocatalytic degradation of rhodamine B under UV irradiation. Journal of Molecular Catalysis A: Chemical. 2015. Vol. 406. P. 97-105.

23. Epifani M. [et al.] Soft chemistry routes to transparent metal oxide thin films. The case of sol-gel synthesis and structural characterization of $\mathrm{Ta}_{2} \mathrm{O}_{5}$ thin films from tantalum chloromethoxide // Thin Solid Films. 2014. Vol. 555. P. 39-41.

24. Wolf M.J. [et al.] Fabrication of ultrathin films of $\mathrm{Ta}_{2} \mathrm{O}_{5}$ by a sol-gel method // Thin solid films. 2013. Vol. 527. P. 354-357.

25. Tyree S. Inorganic Syntheses. Volume IX. McGraw-Hill, New-York, 1967. 80 p.

\section{СВЕДЕНИЯ ОБ АВТOPAX/AUTHORS}

BOGDANOV Evgenii A. - Immanuel Kant Baltic Federal University.

14 A. Nevskogo ul., Kaliningrad, 236041..

E-mail: eubogdanov@gmail.com

БОГДАНОВ Евгений Анатольевич - научный сотрудник Балтийского федерального университета имени Иммануила Канта.

236016, г. Калининград, ул. А.Невского, д. 14.

E-mail: eubogdanov@gmail.com

CHUPAKHIN Evgenii G. - Immanuel Kant Baltic Federal University.

14 A. Nevskogo ul., Kaliningrad, 236041.

E-mail: chupakhinevgen@gmail.com

ЧУПАХИН Евгений Геннадьевич - аспирант Балтийского федерального университета имени

Иммануила Канта.

236016, г. Калининград, ул. А. Невского, д. 14.

E-mail: chupakhinevgen@gmail.com

SOTNIKOV Egor B. - Immanuel Kant Baltic Federal University.

14 A. Nevskogo ul., Kaliningrad, 236041..

E-mail: sotnikovegor94@gmail.com

СОТНИКОВ Егор Борисович - аспирант Балтийского федерального университета имени

Иммануила Канта.

236016, г. Калининград, ул. А. Невского, д. 14.

E-mail: sotnikovegor94@gmail.com

VASILYEVA Ekaterina S. - Skolkovo Institute of Science and Technology.

Skolkovo Innovation Center, Building 3 Moscow 143026 Russia.

E-mail: katrinfr@inbox.ru 
ВАСИЛЬЕВА Екатерина Сергеевна - кандидат технических наук, Facilitator CREI Photonics and Photo electronics, Сколковский институт науки и технологий. улица Нобеля, д. 3 Москва 143026 Россия.

E-mail: katrinfr@inbox.ru

BULANOV Sergei S. - Immanuel Kant Baltic Federal University.

14 A. Nevskogo ul., Kaliningrad, 236041..

E-mail: sbulanovs@gmail.com

БУЛАНОВ Сергей Сергеевич - менеджер Балтийского федерального университета имени Иммануила Канта.

236016, г. Калининград, ул. А. Невского, д. 14.

E-mail: sbulanovs@gmail.com

PATRUSHEV Maksim V. - Immanuel Kant Baltic Federal University.

14 A. Nevskogo ul., Kaliningrad, 236041..

E-mail: maxpatrushev@gmail.com

ПАТРУШЕВ Максим Владимирович - кандидат биологических наук директор Балтийского федерального университета имени Иммануила Канта.

236016, г.Калининград, ул. А.Невского, д.14.

E-mail: maxpatrushev@gmail.com

SHUSHARINA Nataliia N. - Immanuel Kant Baltic Federal University.

14 A. Nevskogo ul., Kaliningrad, 236041..

E-mail: nnshusharina@gmail.com

ШУШАРИНА Наталья Николаевна - кандидат педагогических наук заместитель директора Балтийского федерального университета имени Иммануила Канта.

236016, г. Калининград, ул. А. Невского, д. 14.

E-mail: nnshusharina@gmail.com

GOIKHMAN Aleksandr Y. - Immanuel Kant Baltic Federal University.

14 A. Nevskogo ul., Kaliningrad, 236041.

E-mail: aygoikhman@gmail.com

ГОЙХМАН Александр Юрьевич - кандидат физико-математических наук директор НОЦ «Функциональные наноматериалы» Балтийского федерального университета имени Иммануила Канта.

236016, г. Калининград, ул. А.Невского, 14.

E-mail: aygoikhman@gmail.com 